\title{
IMPLEMENTASI FUNGSI MANAJEMEN PERENCAAAN DAN PENGORGANISASIAN DALAM MENINGKATKAN MUTU PENDIDIKAN MADRASAH
}

\author{
Sabilulhaq ${ }^{1}$, Farida Ummami ${ }^{2}$, Nizam Aulia Rachman ${ }^{3}$, Hanif Fadhilah ${ }^{4}$ \\ Fakultas Agama Islam Universitas Muhammadiyah Malang 1, 2, 3,4 \\ sabilulh534@gmail.com ${ }^{1}$, faridaumami71@ gmail.com ${ }^{2}$, \\ nizamauliarachman@gmail.com ${ }^{3}$, haniffadhilah217@gmail.com ${ }^{4}$
}

Received: 09-06-2021

Revised : 20-07-2021

Accepted: 25-07-2021

\begin{abstract}
Abstrak
Latar Belakang: Menghadapi tuntunan perubahan yang serba cepat akibat kompetisi global dan kemajuan tekhnologi, para pemimpin madrasah harus mampu mengelola sumber daya manusia dengan fokus pada masalah-masalah yang benar-benar penting, maka perlunya meletakkan SDM (Sumber Daya Manusia) sebagai suatu bagian dari perencanaan strategi untuk meningkatkan mutu pendidikan dalam madrasah.
\end{abstract}

Tujuan: Artikel ini bertujuan untuk mengetahui seberapa jauh penerapan fungsi manajemen dalam sebuah madrasah demi meningkatkan mutu pendidikannya.

Metode: Penelitian ini menggunakan metode pendekatan deskriptif kuantitatif yang didukung oleh studi keperpustakaan dari jurnal online, buku dan artikel. Pendekatan ini menggunakan langkah-langkah pengumpulan data dari jurnal, artikel dan buku kemudian dianalisis dan disimpulkan.

Hasil: Dalam berbagai literatur-literatur yang ada bahwasanya masih ada beberapa madarasah yang belum baik dalam mengimplementasikan kedua fungsi tersebut, tetapi ada juga literature yang menjelaskan bahwasanya terdapat madrasah yang sudah baik dalam menerapakan kedua fungsi tersebut.

Kesimpulan: Dengan adanya lembaga pendidikan Islam (Madrasah) yang dapat menerapkan fungsi manajemen yang baik akan dapat langsung berpengaruh terhadap masyarakat dan generasi pemuda di masa kini sampai masa depan.

Kata kunci: manajemen; perencanaan; pengorganisasian.

\section{Abstract \\ Background: Facing the demands of fast-paced change due to global competition and technological advances, madrasa leaders must be able to manage human resources by focusing on issues that are really important, it is necessary to put HR (Human Resources) as a part of strategic planning to improve the quality of education in madrasas. Objective: This article aims to find out how far the implementation of the management function in a madrasah}


is to improve the quality of its education.

Methods: This study uses a quantitative descriptive approach which is supported by literature studies from online journals, books and articles. This approach uses the steps of collecting data from journals, articles and books then analyzed and concluded.

Results: In various existing literatures, there are still some madrasas that are not good at implementing these two functions, but there is also literature that explains that there are madrasas that are already good in implementing these two functions.

Conslusion: With an Islamic educational institution (Madrasah) that can implement a good management function, it will be able to directly affect the community and the younger generation in the present to the future.

Keywords: management; planning; organizing.

Coresponden Author : Farida Ummami

Email : faridaumami71@gmail.com

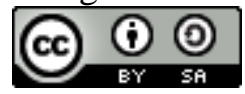

\section{PENDAHULUAN}

Menghadapi tuntunan perubahan yang serba cepat akibat kompetisi global dan kemajuan tekhnologi, para pemimpin madrasah harus mampu mengelola sumber daya manusia dengan fokus pada masalah-masalah yang benar-benar penting, maka perlunya meletakkan SDM (Sumber Daya Manusia) sebagai suatu bagian dari perencanaan strategi untuk meningkatkan mutu pendidikan dalam madrasah (Desy Aniqotsunainy, 2015).

Sebuah sekolah adalah organisasi yang kompleks dan unik. Dikatakan kompleks karena di dalamnya terdapat beberapa elemen yang satu sama lain saling berpengaruh dan saling menentukan. Dikatakan unik karena di sekolah terdapat transfer of knowledge dan transfer of value yang tidak dijumpai pada organisasi lain selain madrasah sehingga memerlukan tingkat koordinasi yang tinggi. Oleh karena itu, kepala madrasah yang berhasil, yaitu tercapainya tujuan madrasah, dan tujuan dari setiap individu yang ada dodalam lingkungan madrasah, harus memahami dan menguasai peranan organisasi dan hubungan kerjasama antar individu. Individu-individu disini adalah guru dan tenaga kelembagaan keagamaan yang melakukan kegiatan dalam rangka mensukseskan proses pembelajaran sebagai bagian dari kegiatan lembaga keagamaan (Talibo, 2018).

Meningkatkan mutu pendidikan dalam madrasah adalah tugas dan tanggung jawab bagi seluruh civitas di madrasah diantara lain ketua yayasan, kepala sekolah, guru, dan sebagainya. Adapun kepala sekolah memiliki peran yang sangat penting dalam peningkatan mutu pendidikan di madrasahnya, yang disesuaikan dengan konteks setempat atau dengan istilah dalam pendidikan dikenal dengan sebutan kontekstual. Peran dan tanggung jawab kepala madrasah dan guru dalam madrasah harus memiliki kemampuan manajerial dalam memanajeman fungsi-fungsi dalam madrasah. Selain dalam lingkup madrasah, juga harus memiliki kemampuan dalam ketatusahaan, membina hubungan madrasah dengan masyarakat dan orang tua, sebagai administrator (Agnes, 2018).

Pendidik dan tenaga kependidikan dituntut untuk memiliki pemahaman yang baik tentang konsep administrasi pendidikan dan memiliki ketrampilan praktis dalam mengelola proses pembelajaran dan administrasi sekolah, agar tujuan pendidikan yang telah ditetapkan dapat tercapai secara maksimal. Selain itu, kepala madrasah sebagai 
manajer lembaga pendidikan juga sangat menentukan kualitas atau keunggulan lembaga pendidikan selain pembelajaran yang dilakukan guru atau pendidik (Habibie, 2019).

Kepala madrasah memiliki peran yang sangat besar, kepala madrasah harus mampu menjadi manajer yang memiliki kemampuan manajerial yang baik dalam hal menyusun perencanaan kegiatan pembelajaran madrasah, menyusun struktur organisasi madrasah, menjadi koordinator dalam organisasi madrasah, mengelola kepegawaian dalam organisasi madrasah, sebagai supervisor dan lain sebagainya (Agnes, 2018).

Keberhasilan madrasah dalam mengelola pendidikan sangat ditentukan oleh kemampuan para civitas madrsah dalam mengimplementasikan fungsi-fungsi manajemen secara professional. Soebadjo Atmodiwiryo dalam bukunya menjelaskan bahwa manajemen pendidikan merupakan suatu proses perencanaan, pengorganisasian, memimpin, mengendalikan tenaga pendidikan, sumber daya pendidikan dalam upaya untuk mencapai tujuan pendidikan. Hakikat manajemen pendidikan dalam madrasah dapat dilihat dari implementasi fungsi-fungsinya yang diawali dari perencanaan, pengorganisasian, pengarahan, pelaksanaan, dan pengawasan.

Dengan demikian, maka setiap madrasah dituntut untuk menyusun, malaksanakan, dan memonitor serta mengevaluasi rencana pengembangan kemajuan madrasah ke depan, untuk memenuhi standar nasional pendidikan tersebut untuk selanjutnya berusaha meningkatkan kualitasnya ke standar lebih tinggi. Upaya tersebut tentunya sangat didukung oleh kompetensi manajerial yang dimiliki kepala madrasah selaku top manager pada madrasah tersebut (Fathul, 2018).

Artikel ini menganalisis dan mendeskripsikan implementasi fungsi manajemen perencanaan dan pengorganisasian dalam pengelolahan Madrasah dengan adanya temuan artikel ini diharapkan dapat membantu dan memperkaya pembelajaran ilmu pengatahuan meneganai implementasi fungsi manajemen perencaan dan pengorganisasian dalam mengelola madrasah, dan dapat dijadikan konsep serta model dalam pengembagan mutu pendidikan Madrasah.

\section{METODE PENELITIAN}

Penelitian ini menggunakan metode pendekatan deskriptif kuantitatif yang didukung oleh studi keperpustakaan dari jurnal online, buku dan artikel. Deskriptif kuantitatif adalah jenis penelitian yang digunakan untuk menganalisis data dengan cara mendeskripsikan atau menggambarkan data yang telah terkumpul sebagaimana adanya penelitian kuantitatif deskriptif menggunakan pendekatan studi keperpustakaan (Library research). Pendekatan ini menggunakan langkah-langkah pengumpulan data dari jurnal, artikel dan buku kemudian dianalisis dan disimpulkan. Menurut M. Nazir dalam bukunya yang berjudul "Metode Penelitian" mengemukakan bahwa yang dimaksud dengan studi keperpustakaan adalah teknik pengumpulan data dengan mengadakan studi penelaahan terhadap buku-buku, literatur-literatur, catatan-catatan dan laporan-laporan yang ada hubungannya dengan masalah yang dipecahkan.

\section{HASIL DAN PEMBAHASAN}

\section{A. Hasil Penelitian}

\section{1) Pengertian Manajemen menurut para ahli}

Menurut James A.F. Stoner, manajemen merupakan proses perencanaan, pengorganisasian, dan pemakaian sumber daya demi tercapainya tujuan perusahaan yang telah ditetapkan. 
Menurut (A. Hidayat \& Machali, 2012), manajemen adalah sebuah proses unik yang terdiri dari berbagai tindakan perencanaan, pengorganisasian, penggerakan dan pengendalian yang dilakukan untuk mencapai target yang telah ditentukan melalui berbagai sumber daya alam maupun manusia.

Menurut Drs. Oey Liang Lee dalam (Suprihanto, 2018), manajemen ialah ilmu untuk merancang, menyusun, mengorganisasikan, mengarahkan, dan mengawasi berbagai kegiatan demi tercapainya tujuan yang telah ditentukan. (Erwinsyah, 2017) mengemukakan bahwa manajemen adalah proses mengkoordinasikan dan mengintegrasikan kegiatan kerja agar diselesaikan secara efektif dan efisien melalui orang lain. Sedangkan Jonshon dalam Made Pidarta (Farikhah, 2015) memberikan definisi manajemen hampir sama dengan pendapat Robbins, yaitu proses mengintegrasikan sumber-sumber yang tidak berhubungan menjadi sistem total mencapai tujuan.

Dari beberapa pendapat para ahli diatas, dapat diambil kesimpulan bahwasanya manajemen merupakan suatu bentuk kerja sama untuk mencapai tujuan itu bersama-saman mengandengan tangan satu sama lain dengan tahapantahapan tertentu.

Hal-hal yang pasti ada dalam manajemen adalah; (a) Manajemen ada tujuan yang akan dicapai bersama (b) Manajemen merupakan perpaduan anatara ilmu dna seni (c) Manajemen merupakan proses yang sistematis, terkoordinasi dan terintegrasi dalam memanfaatkan unsur -unsur manajemen yang disingkat $6 \mathrm{M}$ yakni Men, Money, Methods, Materials, Machines and Market (d) Manajemen dapat diterapkan dalam suatu kegiatan apabila ada dua orang atau lebih yang melakukan kerja sama dalam suatu oraganisasi (e) Manajemen terdiri dari berbagai fungsi yang saling mendukung dan melengkapi (f) Manajemen merupakan alat untuk mencapai tujuan sebuah organisasi.

Lebih lanjut (R. Hidayat, 2016) menekankan adanya ciri-ciri atau pengertian Manajemen Pendidikan yang terkandung dalam definisi tersebut sebagai berikut :

1) Manajemen merupakan kegiatan atau rangkaian kegiatan yang dilakukan dari oleh dan bagi manusia.

2) Rangkaian kegiatan itu merupakan suatu proses pengelolaan dari suatu rangkaian kegiatan pendidikan yang sifatnya kompleks dan unik yang berbeda dengan tujuan perusahaan untuk memperoleh keuntungan yang sebesarbesarnya tujuan kegiatan pendidikan ini tidak terlepas dari tujuan pendidikan secara umum dan tujuan pendidikan yang telah ditetapkan oleh suatu bangsa.

3) Proses pengelolaan itu dilakukan bersama oleh sekelompok manusia yang tergabung dalam suatu organisasi sehingga kegiatannya harus dijaga agar tercipta kondisi kerja yang harmonis tanpa mengorbankan unsur-unsur manusia yang terlibat dalam kegiatan pendidikan itu.

4) Proses itu dilakukan dalam rangka mencapai suatu tujuan yang telah ditetapkan sebelumnya, yang dalam hal ini meliputi tujuan yang bersifat umum (skala tujuan umum) dan yang diemban oleh tiap-tiap organisasi pendidikan (skala tujuan khusus).

5) Proses pengelolaan itu dilakukan agar tujuannya dapat dicapai secara efektif dan efisien.

Manajemen pendidikan dalam kamus bahasa Belanda-Indonesia disebutkan bahwa istilah manajemen berasal dari "administratie" yang berarti tata-usaha. Dalam pengertian manajemen tersebut, administrasi menunjuk pada pekerjaan tulis-menulis di kantor. Pengertian inilah yang menyebabkan timbulnya contohcontoh keluhan kelambatan manajemen yang sudah disinggung, karena manajemen dibatasi lingkupnya sebagai pekerjaan tulis-menulis. 
Dengan demikian dapat disimpulkan bahwasanya manajemen pendidikan adalah suatu proses pengelolaan sumber daya pendidikan baik personal maupun material secara sistematis dan kontinuitas sebagai upaya pencapaian tujuan pendidikan dengan cara efektif dan efesien. (Farikhah, 2015)

Tujuan pokok mempelajari manajemen pendidikan adalah untuk memperoleh cara, teknik, metode yang sebaik-baiknya di lakukan, sehingga sumber-sumber yang sangat terbatas (seperti tenaga, dana, fasilitas, personal, material, maupun spritual) sangat diperlukan untuk mencapai tujuan pendidikan secara efisien dan produktif (Hidayani N, n.d.).

2) Manajemen perencanaan dan pengorganisasian

Manajemen perencanaan adalah suatu proses yang rasional dan sistematik dalam menetapkan keputusan, kegiatan atau langkah-langkah yang akan dilaksanakan di kemudian hari dalam rangka usaha mencapai tujuan secara efektif dan efisien.

Sedangkan perencanaan pendidikan adalah pemilihan fakta-fakta dan usaha menghubung-hubungkan antara fakta yang satu dengan fakta yang lain dalam aktivitas pendidikan, kemudian memprediksi keadaan dan perumusan tindakan kependidikan untuk masa yang akan datang yang sekiranya diperlukan untuk mencapai hasil yang dikehendaki dalam pendidikan.

Makna perencanaan yang digambarkan di atas mengandung arti;

1) Manajer /pimpinan memikirkan dengan matang terlebih dahulu sasaran (tujuan) dan tindakan berdasarkan pada beberapa metode, rencana atau logika dan bukan berdasarkan perasaan.

2) Rencana mengarahkan tujuan organisasi dan menetapkan prodesur terbaik untuk mencapainya.

3) Rencana merupakan pedoman untuk organisasi dalam memperoleh dan menggunakan sumber daya yang diperlukan untuk mencapai tujuan.

Menurut Jejens, dalam perencanaan harus ditentukan delapan aspek; antara lain program kerja, tujuan dan manfaat program, biaya program, waktu, penanggung jawab, pelaksana, mitra, dan asaran (tentu berdasarkan kesepakatan tim kerja yang meliputi unsur pimpinan sebuah lembaga).

Dengan demikian sebuah perencanaan yang ideal dan memang harus disusun secara sistematis dan berdasarkan pada fakta dan data secara kongkrit untuk memastikan apa yang direncanakan betul-betul dapat mengenai sasaran lemba pendidikan. Sehingga kebutuhan perbaikan lembaga dan pengembangannya dapat diakomodir secara jelas oleh para pelaku dalam bentuk rencana yang komprehenship berdasarkan kebutuhan lembaga pendidikan.(Fathul, 2018)

Perencanaan (planning) merupakan bagian dari alur manajemen dalam menentukan pengerak lembaga pendidikan, dari posisi saat ini menuju posisi yang diinginkan di masa depan. Dengan demikian, keberhasilan pencapaian akan ditentukan oleh ketepatan dalam pemilihan strategi dan kemampuan memprediksi kebutuhan lembaga pendidikan di masa yang akan datang. (Fathul, 2018)

Dan dengan sumber daya manusia dalam pendidikan merupakan faktor kunci bagi jalannya organisasi/lembaga pendidikan pada masa kini maupun pengembangan masa depan. Perubahan yang begitu cepat membuat perencanaan strategi menjadi penting, bahkan perencanaan sering bermanfaat sebagai alat untuk memancing pemikiran dan diskusi daripada sebagai proses untuk mendefinisikan tujuan-tujuan jangka panjang dan rangkaian kegiatan.(Desy Aniqotsunainy, 2015)

Fungsi manajemen penggerak juga terdapat dalam fungsi-fungsi manajemen tetapi artikel ini tidak membahasnya terlalu luas. Kegiatan manajemen penggerakan (actuating) atau disebut juga "gerakan aksi" mencakup kegiatan yang dilakukan seorang menejer untuk mengawali dan melanjutkan kegiatan yang 
ditetapkan oleh unsur perencanaan dan pengorganisasian agar tujuan dapat dicapai. (Talibo, 2018)

Menggerakkan (Andrian, Kurniasari, \& Rachman, 2017) berarti merangsang anggota -anggota kelompok melakukan tugas-tugas dengan antusias dan kemauan yang baik. Tugas menggerakkan itu harus dilakukan oleh pemimpin. Oleh karena itu, kepemimpinan kepala Madrasah mempunyai peranan yang sangat penting dalam menggerakkan personal Madrasah dalam melaksanakan kerjanya dan bertanggung jawab atas tugasnya.

Dalam meningkatkan mutu pendidikan itu sendiri untuk mengimplementasikan fungsi manajemen perencanaan terdapat faktor-faktor yang dapat mendukung antara lain; (a) Adanya kerja sama antara kepala Madrasah sebagai penggerak dengan seluruh civitas Madrasah (b) adanya hubungan yang baik antara Madrasah, komite, dan dinas pendidikan (c) sarana prasarana yang cukup memadai. Sedangkan faktor-faktor pemhambat antara lain; (a) kurangnya tenaga kerja guru (b) tidak adanya tenaga administratif (staf tata usaha) (c) tidak adanya pembagian tugas yang jelas (d) kurangnya komunikasi antara kepala Madrasah dan tenaga kerja lainnya (Miss Communicate).

Temuan lain dalam literatur lain dari penelitian ini memiliki makna bahwasanya fungsi utama manajemen perencanaan diimplementasikan dengan melibatkan seluruh sumber daya manusia yang dimiliki oleh madrasah. Perencanaan tidak hanya ditentukan oleh kepala madrasah, akan tetapi juga melalui proses pertimbangan terhadap segala masukan dan informasi yang diberikan oleh guru, komite dan ketua yayasan madrasah. Sehingga jenis kegiatan yang akan dilakukan merupakan hasil kesepakatan bersama melalui rapat internal.

Dampak yang dapat terjadi apabila madrasah tidak dapat menjalankan fungsi-fungsi manjemen dengan baik maka, Madrasah akan mengalami (a) Status akreditasi kurang baik (b) Prestasi akademik maupun non akademik kurang (c) Nilai Ujian Sekolah (US) dan Nilai Ujian Nasional (UAN) dari tahun ke tahun selama tiga tahun terakhir tidak mengalami peningkatan, sedangkan proses belajar mengajar, pembagaian tugas guru mengalami hal yang sama (Agnes, 2018).

Karena adanya dampak yang dapat terjadi tersebut para perencana yang mengatur fungsi manajemen perencanaan harus dapat memanfaatkan fasilitas dan dana yang tersedia atas prinsip pemerataan kesempatan untuk memperoleh pendidikan, dan bekerjasama dengan unsur lain memikirkan batas-batas kebutuhan pasaran tenaga kerja, berapa banyak output pendidikan yang dapat diserap oleh pranata ekonomi dan sosial. Di sini para perencana pendidikan dituntut memiliki kemampuan untuk menyusun rencana, berapa yang diperlukan untuk mendapatkan kesempatan belajar sampai pada tingkat pendidikan tertentu sesuai kebutuhan setelah melalui seleksi secara terbuka dan rasional (Suhada, 2020).

(Mukhsinuddin, 2017) berpendapat bahwa tujuan dilaksanakan perencanaan adalah;

1) Perencanaan bertujuan untuk menetukan tujuan, kebijakan- kebijakan, prosedur, dan program serta memberikan pedoman cara-cara pelaksanaanyang efektif dalam mencapai tujuan.

2) Perencanaan bertujuan untuk menjadikan tindakan ekonomis, karena semua potensi yang dimiliki terarah dengan baik kepada tujuan.

3) Perencanaan adalah satu usaha untuk memperkecil resiko yang dihadapi pada masa yang akan datang.

4) Perencanaan menyebabkan kegiatan-kegiatan yang dilakukan secara teratur dan bertujuan.

5) Perencanaan memberikan gambaran yang jelas dan lengkap tentang seluruh pekerjaan.

6) Perencanaan membantu penggunaan suatu alat pengukuran hasil kerja. 
7) Perencanaan menjadi suatu landasan untuk pengendalian.

8) Perencanaan merupakan usaha untuk menghindari mismanagement dalam penempatan karyawan.

9) Perencanaan membantu peningkatan daya guna dan hasil guna organisasi (Talibo, 2018).

Masih ditemukan literatur-literatur yang membahas kekurangan madrasah dalam mengelola fungsi pengorganisasian sebab realitas yang demikian, apabila dihubungakan dengan konsep pengorganisasian yang baik memang belum bisa disebut madrasah tersebut ideal, karena pengorganisasian secara ideal sebagai pandangan seorang pakar Hikmat, bahwa dalam menjalankan tugas pengorganisasian, terdapat beberapa hal yang diperhatikan oleh pimpinan organisasi, yaitu; a) menyediakan fasilitas, perlengkapan dan staff yang diperlukan untuk melaksanakan rencana kedepannya. b) mengelompokkan dan membagi kerja menjadi struktur organisasi yang teratur dan rapi. c) membentuk struktur kewenangan dan mekanisme koordinasi. D) menentukan metode kerja dan prosedurnya. e) memilih, melatih dan memberi informasi kepada seluruh pegawai madrasah (Fathul, 2018).

Setelah menyusun fungsi perencanaan, selanjutnya diperlukan penyusunan/ pengelompokan kegiatan yang akan dilaksanakan dalam rangka usaha kerja sama. Perlunya pengorganisasian, pengelompokkan tanggung jawab, penyusunan tugas, tugas bagi setiap individu yang mempunyai tanggung jawab (Talibo, 2018).

Mengorganiasikan (organizing) merupakan suatu proses menghubungkan orang-orang yang teribat dalam organisasi tertentu dan menyatupadukan tugas serta fungsinya dalam organisasi. Dalam prosesnya dilakukan pembagian tugas, wewenang, dan tanggungjawab secara terperinci berdasarkan bagian dan bidang masing-masing sehingga terintegrasikan hubungan-hubungan kerja yang sinergis, koperatif, harmonis, dan seirama dalam mencapai tujuan yang telah disepakati (Fathul, 2018).

Dengan demikian, terdapat banyak macam-macam tanggung jawab yang harus dilakukan oleh semua pegawai madrasah sesuai dengan tugas dan kegiatannya, yang dikoordinasi oleh penggerak yaitu seorang kepala madrasah. Koordinasi yang baik akan menghindari terjadinya hal-hal yang tidak diingkan. Dengan begitu semua bagian dan personal individu dapat bekerja sama menuju satu arah yaitu tujuan organisasi/ lembaga pendidikan.

\section{KESIMPULAN}

Sekolah menjadi sebuah organisasi yang terdiri dari beberapa elemen yang satu sama lain saling berpengaruh dan saling menentukan. Di dalamnya juga terdapat transfer of knowledge dan transfer of value yang tidak dijumpai pada organisasi lain selain madrasah sehingga memerlukan tingkat koordinasi yang tinggi.

Memahami dan menerapkan fungsi manajemen dalam sebuah madrasah sangatlah penting sebagai pengimplementasian manajemen pendidikan islam untuk meningkatkan mutu pendidikannya. SDM (Sumber Daya Manusia) juga manjadi bagian penting dari perencanaan strategi untuk meningkatkan mutu pendidikan dalam madrasah. Dalam kelembagaan pendidikan islam (madrasah) dalam menyelenggarakan pendidikan sangat ditentukan dengan kemampuan sumber daya manusia dan pengimplementasian secara professional. Proses pertimbangan yang rasional dan sistematik harus diterapkan dalam menetapkan keputusan, kegiatan atau langkah-langkah yang akan dilaksanakan di 
kemudian hari dan juga rasa tanggung jawab dalam rangka usaha akan berdampak baik dalam mencapai tujuan secara efektif dan efisien.

Maka Dari itu sangatlah penting untuk menerapkan menejemen yang baik dalam merancang, menyusun, mengorganisasikan, mengarahkan, dan mengawasi berbagai kegiatan demi tercapainya tujuan yang telah ditentukan.

\section{BIBLIOGRAFI}

Agnes, A. (2018). Fungsi Perencanaan Dan Penggerak Kepala Sekolah Dalam Meningkatkan Mutu Pendidikan Di Sd Negeri Inpres Hedam Abepura Kota Jayapura. Jurnal Ilmu Pendidikan Indonesia, 6(3), 102-109. https://doi.org/10.31957/jipi.v6i3.607

Andrian, H., Kurniasari, L., \& Rachman, A. (2017). Pengaruh Pemberian Penghargaan terhadap Kedisiplinan Kerja Karyawan CV. Excelso Samarinda Tahun 2016.

Desy Aniqotsunainy. (2015). Penerapan Fungsi Perencanaan Sumber Daya Manusia Dalam Pendidikan. Jurnal Komunikasi Dan Pendidikan Islam, 4(Nomor 2 Desember 2015), 67-80.

Erwinsyah, A. (2017). Manajemen pembelajaran dalam kaitannya dengan peningkatan kualitas guru. Tadbir: Jurnal Manajemen Pendidikan Islam, 5(1), 69-84.

Farikhah, S. (2015). manajemen lembaga pendidikan (Agung, Ed.). Temanggung: Aswaja Pressindo.

Fathul, M. (2018). IMPLEMENTASI FUNGSI-FUNGSI MANAJEMEN DALAM LEMBAGA PENDIDIKAN ISLAM ( Studi Kasus Pengelolaan Madrasah Ibtidaiyah Islahul Muta 'allim Pagutan ). 14(1), 30-50.

Habibie, Y. (2019). Pokoknya admistrasi pendidikan. In Z. Ahmad (Ed.), Penerbit CAHAYA ABADI Tulungangung (Vol. 53). Tulungangung: CAHAYA ABADI Tulungagung.

Hidayani N, M. (n.d.). Pengertian Manajemen Pendidikan. Retrieved from http://langitjinggadipelupukmatarumahmakalah.blogspot.com/2014/10/makalahpengertian-manajemen-pendidikan.html\#

Hidayat, A., \& Machali, I. (2012). Pengelolaan pendidikan: konsep, prinsip, dan aplikasi dalam mengelola sekolah dan madrasah. Bandung: Kaukaba.

Hidayat, R. (2016). Manajemen Peningkatan Mutu Lembaga Pendidikan Islam di Kota Medan. Jurnal Isema: Islamic Educational Management, 1(1).

Mukhsinuddin, M. (2017). Manajemen Membangun Dunia Pendidikan Profesional. BIDAYAH: STUDI ILMU-ILMU KEISLAMAN, 43-52.

Suhada, S. (2020). Problematika, Peranan Dan Fungsi Perencanaan Pendidikan Di Indonesia. Andragogi: Jurnal Pendidikan Islam Dan Manajemen Pendidikan Islam, 2(3), 147-162. https://doi.org/10.36671/andragogi.v2i3.119

Suprihanto, J. (2018). Manajemen. UGM PRESS. 
Sabilulhaq, Farida Ummami, Nizam Aulia Rachman, Hanif Fadhilah/Cerdika: Jurnal Ilmiah Indonesia, 1(7), 858- 866

Talibo, I. (2018). Fungsi Manajemen dalam Perencanaan Pembelajaran. Jurnal Ilmiah Iqra', 7(1). https://doi.org/10.30984/jii.v7i1.606

(C) 2021 by the authors. Submitted for possible open access publication under the

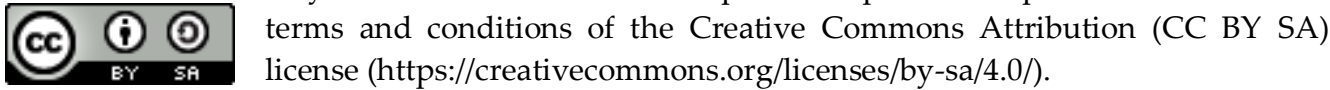

